\title{
OMNISCIENCE, THE INCARNATION, AND KNOWLEDGE DE SE
}

\author{
ANDREI A. BUCKAREFF
}

Marist College

\begin{abstract}
A knowledge argument is offered that presents unique difficulties for Christians who wish to assert that God is essentially omniscient. The difficulties arise from the doctrine of the incarnation. Assuming that God the Son did not necessarily have to become incarnate, then God cannot necessarily have knowledge de se of the content of a non-divine mind. If this is right, then God's epistemic powers are not fixed across possible worlds and God is not essentially omniscient. Some options for Christian theists are discussed, including rejecting traditional theism in favour of some version of pantheism or panentheism.
\end{abstract}

\section{INTRODUCTION}

In this paper I offer a knowledge argument that presents unique difficulties for Christians who wish to assert that God is essentially omniscient. Specifically, I will argue that, if we assume that God the Son did not necessarily have to take on a human nature and become incarnate, God cannot necessarily have knowledge de se of the content of a non-divine mind. If this is right, then some of God's epistemic powers - in this case, the power to have knowledge de se of the contents of a human mind - are not possessed essentially and divine omniscience is not omniscience simpliciter.

Toward the end of this paper I will consider a few options Christians may have in light of the problem raised for traditional Christian theism from orthodox Christology. My guess is that none of these options will be very appealing to orthodox Christian theists.

I will proceed as follows. First, I will discuss an unsuccessful knowledge argument against omniGod theism (the metaphysics of theism on which 
God is understood as essentially omnipotent, omniscient, and omnibenevolent). Next, distinguishing what is known from how it is known and focusing on Christian theism, I offer a new knowledge argument. I then address some objections. Finally, I discuss some options for Christian theists in the face of the problem raised in this paper.

\section{GRIM'S KNOWLEDGE ARGUMENT AND NAGASAWA'S REPLY}

Patrick Grim has argued against generic traditional theism ${ }^{1}$ from knowledge de $s e .^{2}$ Grim argues that no one else, including God, can have knowledge de se of another person. Ergo, divine omniscience is not omniscience simpliciter. If divine omniscience is not omniscience simpliciter, then, assuming that omniscience is an essential attribute of God's, God does not exist (see Nagasawa 2008: 17-18).

Yujin Nagasawa argues that Grim's argument is not sound. ${ }^{3}$ Nagasawa's strategy in response to Grim's argument is to first restate statements about divine omniscience in terms of divine epistemic powers. Epistemic powers qua powers are subsumed by omnipotence. On the most widely accepted view of divine omnipotence, God's failing to be able to do what it is necessarily impossible to do does not undermine divine omnipotence. Because God is not another person (e.g., me or you), God cannot know what that person knows in having knowledge de se. If God could know, then God would be that person. Since God is distinct from that person, it is necessarily impossible for God to have the epistemic power necessary to have such knowledge. So Grim is requiring that God be able to do what it is necessarily impossible to do. This does not undermine God's omnipotence, including God's epistemic powers. So Grim's argument fails (Nagasawa 2008: 21-25). ${ }^{4}$ Given the assumptions expressed by both Grim and Nagasawa about the nature and object of knowing in having knowledge de se, Nagasawa's reply to Grim is a success. ${ }^{5}$

\footnotetext{
${ }^{1}$ By 'theism', Grim clearly means to refer to omniGod theism in his work.

${ }^{2}$ Grim's arguments appear in Grim (1983), (1985), and (2000).

${ }^{3}$ An earlier version of his argument against Grim's argument is in Nagasawa (2003).

${ }^{4}$ Nagasawa considers five objections to his argument that I will not list here. Successful or not, his replies display an impressive concern for rigour that is characteristic of all Nagasawa's arguments in his book.

${ }^{5}$ In chapter three of his book, Nagasawa considers arguments from concept possession based on concept empiricism against traditional theism. Such arguments go from the inability of God to experience states such as fear to the claim that God cannot have the concept of fear.
} 


\section{DIFFICULTIES POSED BY THE INCARNATION AND KNOWLEDGE DE SE}

In this section I offer an argument against divine omniscience from knowledge de se that does not share the liabilities of Grim's argument that make it susceptible to Nagasawa's critique. My argument focuses on difficulties that result from orthodox Christology. I will argue that given certain assumptions about the doctrine of the incarnation, God as understood by traditional Christianity cannot be omniscient simpliciter. Non-Christian theism and variants of Christian theism that do not endorse the orthodox doctrine of the incarnation will not be susceptible to this argument, nor will those that allow for God to relate to the universe differently from how God does on traditional Christian theism. Hence, most Christian pantheists and panentheists who wish to accept some variant of the traditional doctrine of the incarnation will be able to avoid the problem I present. (And in the last section of this paper I briefly discuss how and why at least some possible variants of pantheism and panentheism would be able to avoid the problem generated by the argument presented here.)

\subsection{Knowledge de se}

Suppose we distinguish between how a person believes a proposition from what a person believes (Perry 1994: 182-83). What Ichiro believes when he believes that he is making a mess is the same thing Maria believes when she believes of Ichiro that he is making a mess. Only how they believe what is believed differs from Ichiro to Maria. That is, Ichiro and Maria may both believe the same thing, but in different ways. If we assume this distinction is a correct one to make, then, turning to God and Ichiro, the object of God's knowledge can be the same as the object of Ichiro's knowledge when he believes 'I made a mess'. The intentional object of both God's belief and Ichiro's belief is the same. But while God can know what Ichiro knows when Ichiro knows he made a mess, God knows it in a different way. Furthermore, assuming that God and Ichiro are different persons and neither one is a proper part of the other, there are ways in which God cannot know what they both know. How God knows that Ichiro made a mess is restricted by God's being distinct from Ichiro.

The following two assumptions are worth making clear before proceeding further. First, I am assuming that John Perry (1994) is correct that the object of knowledge in cases of knowledge de se 
includes a sentence. So knowledge de se is a species of knowledge de dicto. Second, I am assuming that the object of knowledge in cases of knowledge de se is a singular sentence. More specifically, I assume that the object of knowledge can be understood as a Russellian proposition, where a Russellian proposition is not a sui generis Platonic entity that is somehow more than what is represented in a representation token such as a sentence. Rather, a Russell proposition 'contains the entities indicated by words' (Russell 1903: 47). So a proposition on this view is a state of affairs that has as its constituents some object or objects and relations and/or properties. The proposition expressed by 'My car is blue' is a state of affairs involving my car and its being blue, and the proposition expressed by 'Andrei is married to Lara' is a state of affairs involving Andrei and Lara standing in the symmetrical relationship of being married to one another. I assume that a sentence is false when what it represents is not made true by anything in the world, and it is true when what it represents is made true by something in the world. Both assumptions are consistent with Perry's views. And they deliver the result that we can distinguish between what is known and how it is known. ${ }^{6}$

The foregoing distinction between what is known and ways of knowing can be further illuminated by the following example. Suppose that you do not speak German. You have a German friend who does not speak English. You both know the same thing, viz., the state of affairs represented by 'Snow is white' and 'Schnee ist weiß'. But the way that you and your friend know the same thing is different. The way you know the proposition in question is through the English sentence above. She knows it via a German sentence. If you were both bilingual, speaking German and English, you would both know it in two different ways. Suppose we add further that you have never actually seen snow. You have seen photos of snow and you have been told that snow is white. Your friend first came to know the colour of snow by direct acquaintance with snow. Thus, how you know what you know is different in yet another way.

\subsection{The incarnation and knowledge de se}

Traditional Christianity asserts that Jesus of Nazareth is one person with two natures. According to the formula of Chalcedon, Jesus is a person

\footnotetext{
${ }^{6}$ Nagasawa (2008) mentions strategies in the debates over knowledge arguments that invoke Russellian propositions briefly in a footnote. But since Grim does not express a commitment to such entities, Nagasawa does not consider such strategies (see Nagasawa 2008: 18, note 7).
} 
who is fully God the Son and fully human. ${ }^{7}$ And God the Son freely took on a human nature in becoming incarnate. The incarnation was not metaphysically or logically necessary according to Christian orthodoxy.

If the two minds account of the incarnation, most recently and thoroughly articulated and defended by Thomas V. Morris (1986) and Richard Swinburne (1994), is correct, then Jesus Christ has two minds, a divine mind and a human mind. On this view, the human consciousness of Christ is contained in his divine consciousness. Timothy Bayne (2001) has referred to this understanding of the incarnation as 'inclusionism.' I will follow Bayne in employing this locution in what follows.

On inclusionism, there is an asymmetrical relationship between the divine and human consciousness such that Jesus qua God the Son has unrestricted first-personal epistemic access to the consciousness of Jesus qua human, but not vice versa. More importantly, as just noted, the divine consciousness contains the human consciousness within it, but not vice versa. Such a relationship allows God to have knowledge de se of what is experienced by Jesus qua human.

As noted above, Christian theism does not assume that God the Son is necessarily incarnate. It was possible for God not to become incarnate. So, to employ the language of possible worlds, there are possible worlds in which God the Son can have knowledge de se of a human consciousness and worlds where God cannot have such knowledge. And whether or not God can have such knowledge depends upon God's relationship to the world - specifically, it depends upon whether God the Son is incarnate in that world.

Consider the following. Suppose that at world $w_{1}$ Jesus is God the Son incarnate. Jesus is in the wilderness, fasting for forty days. Jesus knows that he is hungry. Suppose that the belief component of Jesus's knowing takes as its intentional object the proposition expressed by 'I am hungry right now.' In $w_{1}$, when God is aware of Jesus's hunger, God's knowledge

\footnotetext{
${ }^{7}$ I write in the present tense because traditional Christians take this to be true of Jesus of Nazareth even now (since they believe that he literally ascended to heaven after being resurrected from the dead).

${ }^{8}$ Bayne critiques standard inclusionism and offers a restricted inclusionism as an alternative. I will not worry about his critique of inclusionism here or the details of restricted inclusionism. For a reply to Bayne, see Sturch (2003). Bayne responds in Bayne (2003).

${ }^{9} \mathrm{I}$ here assume that knowledge is justified true belief that is reliably produced by some belief-producing mechanism. However, some epistemologists, e.g., Timothy Williamson (2002), argue that knowing is a mental state. Whether knowing is a mental
} 
of Jesus's hunger can also be expressed as knowledge de se. This is the case because God the Son, qua incarnate divine mind, has the same sort of access relationship to the body of Jesus that the human mind of Jesus bears to the relevant human organism that is in need of food. God the Son knows from the inside that Jesus is hungry. And the way God the Son knows it can be expressed in the same way it is expressed in the human mind of Jesus of Nazareth. Both the divine mind and human mind of Jesus have knowledge de se of the hunger of Jesus. So in $w_{1}$ God has the epistemic power requisite to have knowledge de se of the content of a human mind.

While in $w_{1}$ Jesus Christ is God the Son incarnate, there is some possible world $w_{2}$ in which Jesus does not exist and the incarnation does not occur. So, using the inclusionist framework, in $w_{2}$ we do not have one person with two minds (as we find in $w_{1}$ ). Rather, God the Son is not incarnate in that world. So while in $w_{1}$ God has the power to have knowledge de se of the content of a non-divine mind, in $w_{2}$, since God the Son is not incarnate in that world, God lacks that epistemic power. If this is right, then God's power to have knowledge de se of the contents of a non-divine mind is not a power God necessarily possesses. So God's epistemic power in $w_{1}$ is greater than what God has in $w_{2}$. If that is right, then God's epistemic power is more limited in $w_{2}$. Therefore, God is not essentially omniscient simpliciter.

A summary of the reasoning of this paper thus far is in order before proceeding. I have assumed that if God is omnipotent, God is necessarily omnipotent. I have also assumed that omniscience can be understood in terms of epistemic powers and, hence, in terms of omnipotence. If these two assumptions are correct, then God should have the same epistemic powers in every possible world if God is essentially omniscient. Assuming that God the Son is not incarnate in $w_{2}$, God cannot have knowledge de se of the content of any non-divine mind in that world. But in $w_{1}$, where God the Son is incarnate, God can have knowledge de se of the content of a non-divine mind. If God lacks the epistemic power in $w_{2}$ that God has in $w_{1}$ (where God the Son is incarnate), then God is not essentially omniscient (again, assuming that we can cash out omniscience in terms of epistemic powers).

state or includes a mental state, viz., belief, among its components is unimportant for my purposes here. 


\section{SOME OBJECTIONS}

In this section I consider four objections. None proves fatal to the line of reasoning offered above.

Objection 1: God's epistemic powers do not need to hold fixed across possible worlds in order for God to be necessarily omniscient. Omniscience can be relative to possible worlds. So while God's actual epistemic powers may shift from world to world, so long as God is maximally epistemically powerful in each world, God will be omniscient in that world.

Reply to Objection 1: If God is necessarily omniscient (as traditional theists claim), then the set of God's epistemic powers are fixed across possible worlds. To deny this will get us omniscience on the cheap. If we deny that the set of God's epistemic powers is not fixed across possible worlds, then there would be worlds where God is considerably less epistemically powerful than God is in another world, yet God would still be omniscient in the less powerful world. To say that such a being is omniscient would strain credulity. Moreover, from the standpoint of $w_{1}$ (where God has the power to have knowledge de se of a non-divine mind), the God of $w_{2}$ who has less epistemic power than the God of $w_{1}$ would fail to be omniscient.

If this is right, then it looks like God's having the epistemic power to have knowledge de se of the content of a non-divine mind is not an essential power of God's. So God's epistemic powers are diminished in one world vis-à-vis another because of God the Son's being incarnate in some worlds but not all worlds. If this is right, then God's actual epistemic powers are not held fixed across possible worlds. So God is not necessarily omniscient.

Objection 2: Someone may argue that the epistemic powers God must possess in order to be omniscient does not have to be the same across possible worlds. Rather, there is a set of essential epistemic powers God must possess. The size of that set is determined by what epistemic powers remain stable across possible worlds. So since the power to have knowledge de se of a non-divine mind is not an essential epistemic power that God possesses, that particular epistemic power is not essential for God to be omniscient.

Reply to Objection 2: The proponent of the second objection does not offer any criterion for determining what is or is not an essential power. So the defender of such an objection would need to provide us with 
a criterion for determining what count as essential powers, including epistemic powers. If one is not careful, one may so narrow the set of essential epistemic powers (and powers more generally) that one winds up with something that is hardly worth regarding as omniscience (or omnipotence, for that matter).

Objection 3: This objection is closely related to the previous objections. Someone may hold the following view of powers. An agent $S$ has a power $P$ to do $A$ in the actual world if $S$ does $A$ in some other possible world. So while Ian does not speak Russian in the actual world, Ian has the power to speak Russian because in some possible world he speaks Russian. ${ }^{10}$ Similarly, since there is some world in which God has knowledge de se of the contents of the human mind of Christ, God has this epistemic power in every possible world.

Reply to Objection 3: Such a conception of powers is far too generous. It turns out on this view that a person born blind from birth (suppose she has neither eyes nor visual cortices) has the power of sight in the actual world because there is some possible world where she sees. Consider another example. Suppose that Margaret is very small and weak. She has difficulty lifting anything over $25 \mathrm{~kg}$. On the conception of powers under consideration, Margaret has the power to lift $500 \mathrm{~kg}$ because in some world she is a body builder. If we were to say to a normal person that Margaret actually has the power to lift $500 \mathrm{~kg}$, that person would most likely (justifiedly) laugh in our faces. Margaret has the power to acquire the power to lift $500 \mathrm{~kg}$. But she does not actually possess the power in question. And, in the case of Ian having the power to speak Russian, he has the power to learn to speak Russian. But absent learning to speak Russian, he does not have the power to actually speak Russian.

Similarly, if in $w_{2}$ God the Son is not incarnate and, hence, lacks the power to have knowledge de se of a non-divine mind, then this is a metaphysically more salient fact about God in $w_{2}$ than the fact that God does have the power to have knowledge de se of the content of a nondivine mind in $w_{1}$ because God the Son is incarnate in that world.

Objection 4: While God the Son is not necessarily incarnate, according to orthodox Christology, Jesus Christ is necessarily God the Son incarnate. That is, it was possible for God the Son not to take on a human nature, but Jesus Christ is essentially divine. So in every world in which Jesus exists, Jesus is God. For those worlds in which Jesus does not exist, if Jesus had

${ }^{10}$ Yujin Nagasawa suggested such an objection as well as the response that follows. 
existed in those worlds, then God the Son would be incarnate in Jesus in those worlds. If that is the case, then God would have the power to have knowledge de se of the content of the human mind of Jesus in every possible world. Even if there are possible worlds in which the universe has no other persons, God possesses the relevant epistemic power in those worlds. But those are worlds in which God simply has no opportunity to manifest the relevant epistemic power that God, nonetheless, possesses. Much as $\mathrm{H}_{2} \mathrm{O}$ possesses the power to dissolve $\mathrm{NaCl}$ even in worlds where it never manifests this power because of the absence of salt, so also God possesses the epistemic power in question even in worlds where God cannot manifest the power because God the Son is not incarnate in those worlds. ${ }^{11}$ Hence, God's failing to have knowledge de se of the human mind of Christ is not indicative of a difference between God's powers across possible worlds.

Reply to Objection 4: God's ability to have knowledge de se of a nonhuman mind is a radically contingent power. God can only possess this power (even if never manifested) if God the Son is actually incarnate (i.e., only in a world in which Jesus exists).

Consider the following analogy. Suppose the only thing necessary for transworld identity is something like sameness of first-person perspective. In the actual world, David Beckham has the ability to kick a ball because he has a body with that power. But there is a possible world in which he was born without legs. He does not have the power to kick a ball in that world. It is not a latent power Beckham possesses but just cannot manifest because of his condition. Moreover, in a world without the technology necessary for Beckham to acquire functioning legs with which he can play football, it is not a power that Beckham can come to possess.

Similarly, whether or not God has the epistemic power required to have knowledge de se of the contents of a non-divine mind depends upon whether God the Son is incarnate in that world. God's epistemic powers vis-à-vis the universe are restricted by how God relates to the world. And since God the Son is not necessarily incarnate, then God does not necessarily possess the power to have knowledge de se of the contents of a non-divine mind. Hence, God is not essentially omniscient if orthodox Christology is correct.

${ }^{11}$ For more on the distinction between possessing and manifesting powers, see Martin (2007). 


\section{OPTIONS FOR THE CHRISTIAN THEIST}

Traditional Christian theists who find the foregoing argument compelling have at least three options. Each successive option takes the Christian further from orthodoxy than the previous one.

\subsection{First option: God is not essentially omniscient}

Some Christian theists may find this acceptable. After all, they may argue, what matters is what God is actually like and, they assert, God is actually omniscient, even if God is not essentially omniscient. Some, however, may find the cost of such a move to be too high. But given their other theological commitments, this may be the only viable option for the Christian theist who wishes to endorse orthodox Christology.

\subsection{Second option: reject Chalcedonian Christology}

I suspect that fewer Christian theists will find this option attractive. If one rejects Chalcedonian Christology, there are numerous options. Some are more extreme than others. For instance, one may endorse Apollinarianism, and deny that Jesus had a human mind. This move would result in God lacking knowledge de se of the minds of any created persons. Some may reject the doctrine of the incarnation entirely. But those who wish to at least approximate historical Christianity will find this move unacceptable.

\subsection{Third option: endorse a version of pantheism or panentheism}

The final option is one at which many Christians would balk. But it is worth considering. It is perhaps the most radical solution.

If we accept some version of pantheism or panentheism (and assume the necessary existence of God), then God has knowledge de se of the contents of every mind in every possible world in which there are minds. This is so because the divine consciousness contains the consciousness of the myriad individual minds that populate the universe within it. And because of God's relationship to the universe on this view, this is a power God has in every world since the universe constitutes, is identical with, or is a proper part of God. In some worlds, the universe has no conscious inhabitants. But if there were conscious inhabitants in that universe, God would have knowledge de se of the contents of their minds. God has the power to know the minds of the conscious inhabitants of a world because of how God relates to the universe in that world. The relevant epistemic power in such worlds is simply never manifested, but it is still 
a power possessed much as $\mathrm{H}_{2} \mathrm{O}$ in a universe without $\mathrm{NaCl}$ still has the power to dissolve $\mathrm{NaCl}$.

One worry that some may have is that the uniqueness of the incarnation is lost on this view. Everyone is divine, it might be argued. Of course, any such response would involve committing the fallacy of division. The parts of my Honda Fit are not themselves a Honda Fit. This is clearly the case if an object is a complex substance (such as my car) and the parts are substantial parts, but it is also the case with merely spatial parts. A location in a simple substance is not identical with every location in a substance and it is definitely not identical with the entire substance. ${ }^{12}$ Assuming that God is a substance, whether God is a complex or simple substance, it does not follow that the proper parts (whether substantial if God is complex or merely spatial if God is simple) are also God if pantheism or panentheism is correct. Moreover, it does not follow that God is united to every conscious being in the way God the Son is described as being united to Jesus of Nazareth according to orthodox Christology.

That said, if pan-inclusionism is true, then every created mind would stand to the divine mind as Christ's mind does to God the Son's mind according to inclusionist interpretations of orthodox Christology. Of course, this fact alone would not be enough to establish that all created persons stand in the same sort of relationship to God that Christ does on orthodox Christology (the access relationship between God's and Christ's mind is only one aspect of the incarnation). However, if I am right, then God can have knowledge de se of the contents of every conscious mind, human and non-human, whether or not Jesus exists in a world.

At this point, orthodox Christians will no doubt worry that the doctrine of the incarnation has been effectively thrown out the window. This is not obviously the case. Some work must be done to account for how God could relate uniquely to Jesus of Nazareth in a way suitable to provide the truthmakers for the creedal statements about the incarnation. And most versions of pantheism and panentheism will not fit the bill. Moreover, some variants of pantheism and panentheism that do not conflict with the Chalcedonian formula may still be vulnerable to the sort of knowledge argument presented in this paper. ${ }^{13}$ In any case, the

\footnotetext{
${ }^{12}$ See Heil (2012) for more on spatial versus substantial parts.

${ }^{13}$ For instance, Forrest (2007) presents a variant of panentheism on which individual aware agents are like so many holes in God. God fills one of the holes in the incarnation.
} 
third option for Christians may imply the second option. If they accept some version of pantheism or panentheism, they may have to give up Chalcedonian Christology (and much more).

None of the foregoing is meant to suggest that the task of reconciliation is impossible. It may just require that Christians who accept the third option be as creative and open to resources from outside of the Christian tradition as their early forebears were who first articulated Christian doctrine using the resources provided by Platonism. In any case, such a task goes well beyond the scope of this paper. But I think it is a worthwhile one for Christian philosophical theologians to consider. It requires, however, that they be open to new ways of thinking about the nature of God, especially God's relationship to the universe. If the price is too high to pay for some (and I suspect that most traditional Christians will find accepting any version of pantheism or panentheism to be too high a price to pay), there are always the other options I mentioned. In any case, there are no free lunches in philosophical theology.

\section{CONCLUSION}

My purpose in this essay has not been to attack orthodox Christology. My chief goal was to offer a knowledge argument that presents a unique challenge to orthodox Christian theists. If I am right, then Christians who endorse orthodox Christology and take God to be omniscient must accept one of the options I mentioned in the previous section. This includes, but is not limited to, rethinking how Christians should think about the relationship of God to the universe. ${ }^{14}$

This account of the nature of God can deliver a Christology consistent with orthodoxy, but it falls prey to the sort of knowledge argument presented in this paper.

${ }^{14}$ An earlier version of this paper was presented at the 2010 Central Division Meeting of the American Philosophical Association. Thanks are due to Andrew Cullison, Robert Garcia, Wes Morriston, and especially Yujin Nagasawa for their helpful comments on earlier drafts of this paper. My work on this paper was generously supported by a grant from the John Templeton Foundation (Yujin Nagasawa is my co-investigator) supporting research on 'Alternative Concepts of God'. The views expressed in this paper do not reflect the views of the John Templeton Foundation. 


\section{BIBLIOGRAPHY}

Bayne, Timothy. 2001. 'The Inclusion Model of the Incarnation: Problems and Prospects', Religious Studies, 37: 125-41

Bayne, Timothy. (2003) 'Inclusion and Incarnation: A Reply to Sturch', Religious Studies, 39: 107-109

Forrest, Peter. 2007. Developmental Theism: From Pure Will to Unbounded Love (New York: Oxford University Press)

Grim, Patrick. 1983. 'Some Neglected Problems of Omniscience', American Philosophical Quarterly, 20: 265-76

Grim, Patrick. 1985. Against Omniscience: The Case From Essential Indexicals', Noûs, 19: 151-80

Grim, Patrick. 2000. 'The Being That Knew Too Much', International Journal for Philosophy of Religion, 47: 141-54

Heil, John. 2012. 'Substances Stressed', in P. Goff (ed.), Spinoza on Monism (New York: Palgrave-Macmillan), pp. 167-180

Martin, C.B. 2007. The Mind in Nature (New York: Oxford University Press)

Mander, William. 2000. 'Omniscience and Pantheism', The Heythrop Journal, 41: 199-208

Morris, Thomas V. 1986. The Logic of God Incarnate (Ithaca: Cornell University Press)

Nagasawa, Yujin. 2003. 'Divine Omniscience and Knowledge de se', International Journal for Philosophy of Religion, 53: 73-82

Nagasawa, Yujin. 2008. God and Phenomenal Consciousness: A Novel Approach to Knowledge Arguments (New York: Cambridge University Press)

Perry, John. 2004. 'The Problem of the Essential Indexical', reprinted in Q. Cassam (ed.), Self-Knowledge (New York: Oxford University Press), pp. 167-83

Russell, Bertrand. 1903. The Principles of Mathematics, volume 1 (Cambridge: Cambridge University Press)

Sturch, Richard. 2003. 'Inclusion and Incarnation: A Response to Bayne', Religious Studies, 39: 103-106

Swinburne, Richard. 1994. The Christian God (New York: Oxford University Press)

Williamson, Timothy. 2002. Knowledge and its Limits (New York: Oxford University Press) 